\title{
A study on the effects of subsidies on market value of listed companies in Tehran Stock Exchange
}

\author{
Leyla Osati ${ }^{\mathrm{a}}$ and Mohsen Hamidian ${ }^{\mathrm{b}^{*}}$
}

${ }^{a}$ Department of management and Accounting, South Tehran Branch, Islamic Azad University, Tehran, Iran ${ }^{b}$ Faculty member, Department of management and Accounting, South Tehran Branch, Islamic Azad University, Tehran, Iran

\begin{tabular}{l}
\hline C H R O N I C L E \\
\hline Article history: \\
Received October 28, 2014 \\
Received in revised format 2 \\
February 2015 \\
Accepted 4 February 2015 \\
Available online \\
February 4 2015 \\
\hline Keywords: \\
Tehran Stock Exchange \\
Subsidy removal \\
Cement industry \\
Auto industry \\
\hline
\end{tabular}
\begin{abstract}
A B S T R A C T
According to the $4^{\text {th }}$ Iran's development plan, there must an increase in energy prices and removal of subsidies paid to energy sector. Therefore, it is necessary to study the effects of removing subsidies paid on energy on different industries and the subsequent impact on economic growth. This study aims to investigate the effects of subsidies on the market value of listed companies in Tehran Stock Exchange in automotive and cement industries. The study selects two firms, Fars \& Khuzestan Cement Co. and Irank Khodro using Auto Regressive Distributed Lags (ARDL) over the period 2008-2013. The results of study have indicated that there was a meaningful relationship between removal of subsidies and market value of the firms.
\end{abstract}

(c) 2015 Growing Science Ltd. All rights reserved.

\section{Introduction}

Subsidies in Iranian community are indirect or direct payments as a financial assistance, economic points or giving special excellences to private agencies, households as well as governmental units to reach desired goals (Brooks, 2003). According to HooriJafari and FarahmandPur (2008), the subsidy includes all kinds of transitive payments to provide some supports for the low-income and vulnerable communities and to contribute the income distribution for households or industries given by the state treasury. Government subsidy is described as the difference between the finished and the adjusted prices of products or services devoted by the government in support of the target group proportion to their income, the target group may reach desirable buying power and suitable quality of life. Normally, the amount of required subsidy is specified as subtraction of the finished price of products or services and the level of public purchasing ability (Mirzamohammadi et al., 2012). There are several studies on the effects of subsidy removal on economic circumstances. 
Koozehgar et al. (2014) investigated the welfare consequences of self-targeted subsidies in Iran. The study attempted to realize whether or not transferring one unit of subsidies given on the subsidized goods mostly used by the rich people to the nonsubsidized goods mostly used by the poor could positively contribute to social welfare. For this purpose, using Atkinson social welfare function, they estimated the change in social welfare created by self-targeted subsidies. They reported that selftargeted subsidies could increase social welfare. The extent of this increase was negatively associated with inequality aversion parameter, while positively associated with the share of nonsubsidized goods in low income deciles budget.

Iravani et al. (2012) presented a survey to measure the effects of recent economic reform based on subsidy removal on Iranian economic factors including inflation, unemployment, tuition fee, consumer consumption pattern and city transportation facilities. They reported that there was a meaningful relationship between government subsidies and unemployment, transportation facilities, consumer consumption pattern. However, the survey did not find any evidence to believe that there was any relationship between government subsidies and inflation, increase in tuition fee.

Schwartz and Clements (1999) discussed the problems of defining and measuring government subsidies, examined why and how government subsidies were applied as a fiscal policy tool, discussed their general economic impacts in terms of real welfare expenses and distributional implications, appraised international empirical evidence on government subsidies, and offered options for their reform. Ahearn et al. (2006) investigated the effect of coupled and decoupled government subsidies on off-farm labor participation of US farm operators. Zhang et al. (2014) investigated the relationship among political connections, government subsidies and firm financial performance of wind and solar manufacturing companies. They reported that government subsidies, in long and short-terms, had positive effects on the financial performance of wind energy manufacturing companies. In their study, both key variables, government subsidies and an interaction term of subsidies as well as political connections, did not have meaningful impacts on the financial performance of solar energy manufacturing firms.

Sun et al. (2014) tested the effect of biogas subsidies on household biogas energy usage in rural China. They focused on the problem of sample selection bias in evaluating the effect of subsidies on biogas energy use because biogas subsidies may change the propensity for installing biogas digesters. They reported that biogas subsidies did promote the construction of biogas digesters. Their results implied that a 10 percentage point increase in subsidy-cost ratio could result to a $3 \%$ increase in digester installations. They also reported that biogas subsidies was associated negatively with average time of digester use. In their survey, $10 \%$ increase in the subsidy-cost ratio could yield in a $4.3 \%$ reduction in the average working time of digesters. These results indicated that the net impact of the current subsidy policy on rural household biogas use was near-negligible. The results indicated that biogas subsidies had possibly not been targeted effectively at households that would actually prefer to use biogas energy.

López and Galinato (2007) empirically investigated the impacts of subsidizing private products to the detriment of the government's supply of public goods. They applied a new data set from the rural sector in 15 Latin American countries over the period 1985-2001 collected based on a methodology, which could help us separate government subsidies to private goods from expenditures in the provision of public goods. They reported that the government's decision to subsidize either private or public goods maintained dramatic consequences for economic development.

According to Kleer (2010), government subsidies for research and development (R\&D) could be intended to promote projects with high returns to society but too little private returns to be beneficial for private investors. They applied a simple signaling model with different kinds of R\&D projects to capture this phenomenon. The agency had a preference for basic research projects as they expect high expected social returns, while banks prefer applied research projects with high private returns. 


\section{The propsoed study}

This study aims to investigate the effects of subsidies on the market value of listed companies in Tehran Stock Exchange in automotive and cement industries. The study selects two firms, Fars \& Khuzestan Cement Co. and Irank Khodro using Auto Regressive Distributed Lags (ARDL) over the period 20082013. The advantage ARDL method is that regardless of whether the explanatory variables are I (0) or I (1), it can examine the relationship among convergence of variables. An ARDL model can be expressed as follows,

$$
\begin{aligned}
& Q(L . s) Y_{t}=\sum_{i=1}^{k} \theta_{t}\left(L, n_{t}\right) X_{i t}+\delta^{\prime} W_{t}+u_{t}, \\
& Q(L . s)=\left(1-\alpha_{1} l-\alpha_{2} l^{2}-\ldots-\alpha_{s} l^{s},\right. \\
& \theta\left(L, n_{t}\right)=\theta_{l 0}+\theta_{l 1} L+\theta_{l 2} L^{2}+\ldots+\theta_{\mathrm{ln}_{l}} L^{n_{l}},
\end{aligned}
$$

where $L$ is the first order time delay operator such that $L X_{t}=X_{t-1}, y_{t}$ is a dependent variable, $X_{i t}$ is the vector of independent variables, $K$ represents the number of explained variables, $n_{1}, n_{2}, \ldots n_{t}$ are the number of optimum interruptions for independent variables and finally, $S$, is the number of optimum interruptions for dependent variable. In addition, $w_{t}$ is the vector of deterministic variables such as the intercept, seasonal variables, time or exogenous variables defined and estimated using ordinary least square (OLS) technique for all values for $s=0,1,2, \ldots . d, n_{t}=0,1,2, \ldots . d, i=0,1,2, \ldots k$. In other words, $(d+1)^{k+1}$ numbers of ARDL models are estimated where the maximum number of interruptions is determined by $d$ and for all models we have $t=d+1, \ldots n$. Error correction model fits ARDL model is as follows,

$$
\Delta y_{i}=-Q(L, \hat{s}) E C T_{t-1}+\sum_{i=1}^{k} \theta_{l 0} \Delta x_{i t}+\delta^{\prime} \Delta w_{t}-\sum_{j=1}^{\hat{s}-1} Q^{*} \Delta y_{t-j}-\sum_{i=1}^{k} \sum_{j-1}^{\hat{n} i-1} \theta^{*} i j \Delta x_{t, i-j}+u_{t}
$$

where $\Delta w_{t}, \Delta x_{i t}, \Delta y_{t}$ represent vectors of deterministic, independent and dependent variables, respectively. In addition, $Q^{*}, \theta^{*} i j$ represent error correction coefficients.

There are two variables associated with the proposed study of this paper,

1. Industry index performance (growth): This index is calculated for each industry separately. In this study, the indicator for the cement industry and the automotive industry and using information from companies listed in Tehran Stock Exchange for the period 2008-2013 have been used.

2. The overall market index: This index demonstrates positive and negative market trends and also provides a mean of comparison with the past. The study selects two firms, Fars \& Khuzestan Cement Co. and Irank Khodro over the period 2008-2013. We expect that as the economy grows, overall index market increases and consequently industry sector also increases, too. This study presents the results of three models; namely Dynamic, Error-Correction and Long-run of subsidy removal on market.

\section{The results}

\subsection{Cement Industry}

We first investigate the effects of subsidy removal on cement industry. Table 1 demonstrates the results of ADRL dynamic. 


\section{Table 1}

The summary of the results of ADRL dynamic

\begin{tabular}{llccc}
\hline Row & & Coefficient & t-value & Sig. \\
\hline 1 & Intercept & 5.87 & 4.33 & 0.000 \\
2 & Cement industry index & -0.46 & -3.54 & 0.002 \\
\hline
\end{tabular}

R-Square $=0.79$, F-value $=8.11$, Sig. $=0.000, \mathrm{D}-\mathrm{W}=2.67$

The results of Table 1 indicate that both coefficients are meaningful when the level of significance is one percent. R-Square value is equal to 0.79 , which means the independent variable describes $79 \%$ of the changes on dependent variable. Moreover, F-value is statistically meaningful, which means the relationship is linear and Durbin-Watson value is equal to 2.67, which means there is no autocorrelations among residuals. As we can observe from the results of Table 1, the increase on energy prices as a results of subsidy removal has influenced negatively on the performance of cement industry. Table 2 demonstrates the results of ADRL Correction-Error

Table 2

The summary of the results of ADRL Correction-Error

\begin{tabular}{llccc}
\hline Row & & Coefficient & t-value & Sig. \\
\hline 1 & Intercept & 5.87 & 4.33 & 0.000 \\
2 & Cement industry index & -0.46 & -3.54 & 0.002 \\
3 & Ecm $(-1)$ & -0.32 & -6.9 & 0.000 \\
\hline
\end{tabular}

The results of ADRL correction-Error model are similar to Table 1, which means energy subsidy has negative impact on cement industry. Finally, Table 3 presents the results of Long-run of subsidy removal on market, whose results are consistent with Dynamic and Correction-Error models. In our survey, over the long term, an increase on energy prices has negative consequences on cement industry.

Table 3

The summary of the results of ADRL Long-run

\begin{tabular}{llccc}
\hline Row & & Coefficient & t-value & Sig. \\
\hline 1 & Intercept & 0.055 & 5.92 & 0.000 \\
2 & Cement industry index & -0.74 & 3.68 & 0.002 \\
\hline
\end{tabular}

\subsection{Auto Industry}

We next investigate the effects of subsidy removal on auto industry. Table 4 presents the results of ADRL dynamic.

Table 4

The summary of the results of ADRL dynamic

\begin{tabular}{llccc}
\hline Row & & Coefficient & t-value & Sig. \\
\hline 1 & Intercept & 4.31 & 6.45 & 0.000 \\
2 & Auto industry index & 0.006 & 1.90 & 0.002 \\
\hline R-Square $=$ & 0.71, F-value $=$ 7.10, Sig. $=0.000, \mathrm{D}-\mathrm{W}=2.641$ & & &
\end{tabular}

The results of Table 4 show that both coefficients are meaningful when the level of significance is one percent. R-Square value is equal to 0.71 , which indicates the independent variable describes $71 \%$ of the changes on dependent variable. Moreover, F-value is statistically meaningful, which means the relationship is linear and Durbin-Watson value is equal to 2.641, which means there is no autocorrelations among residuals. As we can observe from the results of Table 4, the increase on energy prices as a results of subsidy removal has influenced positively on the performance of auto industry. Table 5 demonstrates the results of ADRL Correction-Error 
Table 5

The summary of the results of ADRL Correction-Error

\begin{tabular}{llccc}
\hline Row & & Coefficient & t-value & Sig. \\
\hline 1 & Intercept & 4.31 & 6.45 & 0.000 \\
2 & Auto industry index & 0.006 & 1.90 & 0.002 \\
3 & Ecm (-1) & -0.39 & -8.36 & 0.000 \\
\hline
\end{tabular}

The results of ADRL correction-Error model are similar to Table 4, which means energy subsidy has positive impact on cement industry. Finally, Table 6 presents the results of Long-run of subsidy removal on market, whose results are consistent with Dynamic and Correction-Error models. In our survey, over the long term, an increase on energy prices has positive consequences on auto industry.

\section{Table 6}

The summary of the results of ADRL Long-run

\begin{tabular}{llccc}
\hline Row & & Coefficient & t-value & Sig. \\
\hline 1 & Intercept & 4.44 & 5.98 & 0.000 \\
2 & Auto industry index & 0.04 & 2.58 & 0.002 \\
\hline
\end{tabular}

\section{Discussion and conclusion}

In this survey, we have presented an empirical investigation to study the effects of energy prices on the performance of cement and auto industries. Using different ADRL models, the study has concluded that the subsidy removal has negatively influenced on cement industry and positively affected the auto industry. The results of this survey shed light on the effects of subsidy removal on other industries. Cement industry consumes high level of energy and any increase in energy price increases cost of production. On the other hand, cement price is regulated by government and firms are not allowed increasing it on market. The increase of cost of production and limitations on cement price for some years have negatively influenced the cement industry. In Auto industry, on the other hand, energy does not directly play essential role on cost of production. Therefore, as expected, deregulation on energy prices may not influence significantly on auto industry.

\section{Acknowledgement}

The authors would like to thank the anonymous referees for constructive comments on earlier version of this paper.

\section{References}

Ahearn, M. C., El-Osta, H., \& Dewbre, J. (2006). The impact of coupled and decoupled government subsidies on off-farm labor participation of US farm operators. American Journal of Agricultural Economics, 88(2), 393-408.

Brooks, A. C. (2003). Do government subsidies to nonprofits crowd out donations or donors?. Public Finance Review, 31(2), 166-179.

HooriJafari, H., \& FarahmandPur, B. (2008). Energy loans and its effect on the different parts of economics. Journal of Energy Economics Surveys, 2, 162-178.

Iravani, M., Kelari, B., Taghipour, F \& Tajbakhsh, G. (2012). A social work study on measuring the impact of government subsidies reform on economy. Management Science Letters, 2(8), 2917-2922.

Koozehgar, P., Pourghaz, G \& Ortaboulagi, S. (2014). The impact of self-targeted subsidies on social welfare in Iran. Management Science Letters, 4(7), 1531-1536.

Kleer, R. (2010). Government R\&D subsidies as a signal for private investors. Research Policy, 39(10), 1361-1374. 
López, R., \& Galinato, G. I. (2007). Should governments stop subsidies to private goods? Evidence from rural Latin America. Journal of Public Economics, 91(5), 1071-1094.

Mirzamohammadi, S., Ghaderi, F \& Ardakani, M. (2012). Assessing the effects of removing of energy subsidies on urban passenger transportation within the city of Tehran based on a system dynamics approach. Management Science Letters, 2(6), 2125-2134.

Schwartz, G., \& Clements, B. (1999). Government subsidies. Journal of Economic Surveys, 13(2), 119148.

Sun, D., Bai, J., Qiu, H., \& Cai, Y. (2014). Impact of government subsidies on household biogas use in rural China. Energy Policy, 73, 748-756.

Zhang, H., Li, L., Zhou, D., \& Zhou, P. (2014). Political connections, government subsidies and firm financial performance: Evidence from renewable energy manufacturing in China. Renewable Energy, 63, 330-336. 